\title{
PENGARUH PENAMBAHAN PEPPERMINT (Mentha piperita, L.) TERHADAP KUALITAS TEH DAUN PEGAGAN (Centella asiatica, L. Urban)
}

\author{
The Influence of Peppermint (Mentha piperita, L.) Addition on The Quality \\ of Pegagan Leaves Tea (Centella asiatica, L. Urban)
}

Tuty Anggraini*, Diana Silvy, Sahadi Didi Ismanto, dan Firdaus Azhar

Fakultas Teknologi Pertanian, Universitas Andalas

Limau Manis, Padang 25163

*email: tuty_anggraini@yahoo.co.id

Diterima: 12 Agustus 2014, revisi akhir: 3 Desember 2014 dan disetujui untuk diterbitkan: 8 Desember 2014

\begin{abstract}
ABSTRAK
Penelitian ini bertujuan untuk mengetahui pengaruh penambahan ekstrak peppermint terhadap kualitas teh daun pegagan. Penelitian menggunakan Rancangan Acak Lengkap (RAL) yang terdiri dari 5 perlakuan dan 3 kali ulangan. Data dianalisis secara statistika dengan menggunakan ANOVA dan jika berbeda nyata, dilanjutkan dengan uji Duncan's New Multiple Range Test (DNMRT) pada taraf nyata $5 \%$ dengan perlakuan: tanpa penambahan ekstrak peppermint, penambahan ekstrak peppermint 1,2, 3, dan $4 \%$. Pengamatan pada teh daun pegagan dengan penambahan ekstrak peppermint meliputi uji kadar air, kadar abu, uji aktivitas antioksidan, uji kualitatif senyawa triterpenoid dan steroid, uji kualitatif senyawa golongan alkaloid, uji kandungan total polifenol, dan uji organoleptik. Hasil penelitian menunjukkan bahwa penambahan ekstrak peppermint berpengaruh nyata terhadap uji kadar air, kadar abu, aktivitas antioksidan, dan kandungan total polifenol teh daun pegagan yang dihasilkan. Hasil uji organoleptik menunjukkan penambahan ekstrak peppermint $4 \%$ sebagai produk terbaik dengan nilai kadar air (4,10\%), kadar abu (14,23\%), aktivitas antioksidan $(55,22 \%)$, mengandung senyawa triterpenoid dan steroid, mengandung senyawa alkaloid, dan nilai total polifenol $(11,88 \%)$.
\end{abstract}

\section{Kata Kunci: Antioksidan, ekstrak peppermint, teh daun pegagan, triterpenoid}

\section{ABSTRACT}

The aim of this research was to determine the effect of peppermint extract toward quality of pegagan leaves tea. The research using a completely randomized design (CRD) consisted of 5 treatments and 3 replications. Data was analyzed statistically using ANOVA that followed by a test of Duncan's New Multiple Range Test (DNMRT) at the $5 \%$ significance level. The treatments were without the addition of peppermint extract, addition of peppermint extract 1, 2, 3, and 4\%. Observation of the pegagan leaves tea consisted of moisture content, ash content, antioxidant activity test, a qualitative test of triterpenoids and steroids compounds, qualitative test of alkaloids compounds, total polyphenol content, and sensory evaluation. The results showed that the addition of peppermint extract significantly affected the moisture content, ash content, antioxidant activity and total polyphenol content of pegagan leaves tea. The results of sensory evaluation showed that the addition of $4 \%$ pepermint extract was the best treatment with water content (4.10\%), ash content (14.23\%), antioxidant activity (55.22\%), containing triterpenoid and steroid compounds, containing alkaloid compound, and total polyphenols value $(11.88 \%)$.

\section{Keywords: Antioxidant, peppermint extract, pegagan leaves tea, triterpenoid}




\section{PENDAHULUAN}

Teh merupakan minuman yang paling banyak dikonsumsi setelah air putih dan dipercaya memiliki banyak manfaat.Teh terbagi menjadi dua jenis, yaitu teh nonherbal dan teh herbal.Teh non-herbal berasal dari tanaman teh (Camelia sinensis). Teh non-herbal dikelompokkan menjadi 3 golongan yaitu teh hitam, teh hijau, dan teh oolong.Teh herbal biasanya terbuat dari akar, batang, bunga, daun, biji, dan kulit buah dari tanaman yang memiliki manfaat sebagai tanaman obat, mudah larut dalam air panas serta mudah dalam penyajian. Tidak seperti teh non-herbal, teh herbal tidak mengandung kafein, sehingga cocok digunakan sebagai detoksifikasi tubuh (Wahyuningsih, 2011). Manfaat teh herbal tersebut dapat diperoleh dari berbagai tanaman, salah satu tanaman yang dapat dijadikan teh herbal adalah pegagan.

Pegagan ditetapkan sebagai tanaman obat di berbagai negara dan secara turun temurun dimanfaatkan untuk mengobati berbagai penyakit. Di Australia pegagan dijadikan sebagai obat dengan nama gotu kola yang bermanfaat sebagai anti pikun dan anti stress. Di China, India, dan Sri Langka pegagan dimanfaatkan sebagai obat untuk memperlancar sirkulasi darah bahkan dianggap lebih bermanfaat dibandingkan dengan ginko biloba atau ginseng (Januwati dan Yusron, 2004).

Pegagan memiliki kandungan seperti polifenol, flavonoid, $\beta$ karoten, tannin dan vitamin $C$, saponin seperti madecassida dan asiaticosida (Rahman et al., 2013; Mahapatra and Kumar, 2012). Asiaticosida yang terdapat pada pegagan berfungsi sebagai antioksidan yang dapat menangkal radikal bebas dan merevitalisasi pembuluh darah (Prabowo, 2002). Pegagan biasa dimanfaatkan sebagai obat tradisional baik dalam bentuk bahan segar, ekstrak, kering maupun jamu (Lasmadiwati, 2003). Salah satu olahan pegagan yang perlu dikembangkan adalah teh pegagan. Teh pegagan merupakan teh herbal berwarna hijau yang berasal dari daun pegagan berbentuk serbuk dari proses pengeringan menggunakan cabinet dryer pada suhu $70^{\circ} \mathrm{C}$ selama 60 menit selanjutnya diayak dengan ukuran 20 mesh. Sifat fisik pegagan diantaranya memiliki rasa yang pahit, sepat, tajam, dan sedikit manis (Winarto dan Surbakti, 2003).

Untuk mengurangi rasa sepat dan pahit yang terkandung didalam tanaman pegagan, ditambahkan peppermint (Mentha piperita, L.) dalam proses pembuatan teh pegagan. Menurut Alankar (2009), peppermint dalam bentuk ekstrak memiliki berbagai macam ester terutama menthyl asetat dan monoterpen yang menghasilkan aroma dan flavor (minty) khas. Penelitian ini bertujuan untuk mendapatkan teh daun pegagan yang diperkaya dengan peppermint yang berfungsi untuk memperkaya antioksidan dan menyamarkan rasa pahit dari daun pegagan. Penambahan peppermint diberikan dalam beberapa konsentrasi berbeda untuk menentukan pada kosentrasi berapa teh memiliki sifat organoleptik berupa aroma, rasa, dan warna teh pegagan yang baik.

\section{METODOLOGI PENELITIAN}

Bahan baku yang digunakan pada penelitian ini adalah daun pegagan segar dengan ciri-ciri daun yang berwarna hijau dan masih segar, bentuk utuh serta berdiameter $3-5 \mathrm{~cm}$ yang diperoleh dari Nagari Pariangan, Kabupaten Tanah Datar. Peppermint yang digunakan berbentuk serbuk kristal yang dibeli di Toko Berkah, Pasar Raya Padang. Bahan kimia yang digunakan yaitu: etanol $96 \%$ (Merk), larutan $\mathrm{DPPH}$ (Merk), reagen Dragendorf, $\mathrm{HCl} 2 \mathrm{~N}$, kloroform beramonia, eter, asam asetat anhidrat, reagen Follin-Ciocalteu 50\%, larutan $\mathrm{Na}_{2} \mathrm{CO}_{3} 7,5 \%$, larutan asam galat, larutan $\mathrm{H}_{2} \mathrm{SO}_{4} 98 \%$, metanol, dan aquadest.

Alat yang dibutuhkan dalam penelitian yakni timbangan, pisau, gunting, oven, loyang, kompor, sendok, baskom, cabinet dryer, ayakan 20 mesh dan blender. Alat yang digunakan dalam analisis adalah timbangan analitik, ultrasonic bath, gelas ukur, spektrofotometer UV-VIS, vortex, micrometer pipet, aluminium foil, spatula, corong pemisah, cawan aluminium, gelas piala, cawan porselen, tanur, tabung reaksi, labu takar, erlenmeyer, pipet tetes, kertas saring, dan desikator. 


\section{Rancangan Penelitian}

Penelitian ini menggunakan Rancangan Acak Lengkap (RAL) dengan 5 perlakuan dan dilakukan 3 kali ulangan. Data yang diperoleh dianalisis menggunakan sidik ragam dengan uji F. Jika $F$ hitung lebih besar dari $\mathrm{F}$ tabel, maka akan dilanjutkan dengan uji Duncan's New Multiple Range Test (DNMRT) pada taraf 5\%. Jumlah bubuk teh daun pegagan adalah 2 gram per sachet tea bag. Perlakuan pada penelitian ini yaitu:

A (tanpa penambahan ekstrak peppermint), B (penambahan ekstrak peppermint $1 \%$ ), C (penambahan ekstrak peppermint $2 \%$ ), $\mathrm{D}$ (penambahan ekstrak peppermint $3 \%$ ), $\mathrm{E}$ (penambahan ekstrak peppermint $4 \%$ ).

\section{Pelaksanaan Penelitian}

\section{Pembuatan Teh Daun Pegagan}

(Modifikasi Irwanto, 2012)

Pemetikan daun pegagan segar yang berwana hijau dengan ukuran diameter 3 - 5 $\mathrm{cm}$. Daun pegagan dipisahkan dengan batangnya sebelum dicuci. Pegagan dicuci untuk menghilangkan kotoran yang ada. Proses selanjutnya adalah pelayuan dengan cara steam (uap panas) yang berfungsi untuk menurunkan kadar air pada daun pegagan selama \pm 5 menit. Selanjutnya dilakukan proses pengeringan dengan menggunakan cabinet dryer pada suhu $70^{\circ} \mathrm{C}$ selama 60 menit. Proses pengecilan ukuran dengan blender lalu diayak pada ukuran 20 mesh sehingga terbentuk serbuk teh daun pegagan.

\section{Pencampuran Teh Daun Pegagan dengan Ekstrak Peppermint}

Bubuk teh daun pegagan sebanyak $2 \mathrm{~g}$ per sachet tea bag ditambahkan dengan ekstrak peppermint sesuai dengan perlakuan yang ditetapkan yaitu A $(0 \%)$, B $(1 \%), C(2 \%)$, D $(3 \%)$, dan E $(4 \%)$. Proses homogenisasi supaya ekstrak peppermint yang ditambahkan tercampur merata. Teh daun pegagan yang telah dicampurkan dengan ekstrak peppermint dikemas dalam teabag.

\section{Pengamatan}

Pengamatan yang dilakukan meliputi pengamatan bahan baku yaitu kadar air (AOAC, 1995) dan kadar abu (Sudarmadji et al., 1997), dan pengamatan pada produk teh daun pegagan dengan penambahan ekstrak peppermint yaitu kadar air (AOAC, 1995), kadar abu (Sudarmadji et al., 1997), Uji Aktivitas Antioksidan dengan Metode DPPH (Molyneuk, 2004 cit Anggia 2011), Uji Kualitatif Senyawa Triterpenoid dan Steroid (Harborne, 1987), Uji Alkaloid Kualitatif (Metode Culvenor dan Fritzegerald, cit Putri, 2012), Uji Kandungan Total Polifenol (Taga, Miller and Pratt, 1984), dan Uji Organoleptik (Rahayu, 1994).

\section{HASIL DAN PEMBAHASAN}

\section{Analisis Bahan Baku}

Analisis bahan baku bertujuan untuk mengetahui kualitas dari bahan baku yang digunakan. Analisis bahan baku yang dilakukan terhadap teh daun pegagan adalah kadar air dan kadar abu. Hasil analisis bahan baku teh daun pegagan dapat diamati pada Tabel 1.

Tabel 1. Hasil analisis bahan baku teh daun pegagan

\begin{tabular}{lc}
\hline Parameter & Teh daun pegagan (\%) \\
\hline KadarAir & 4,05 \\
KadarAbu & 13,22 \\
\hline
\end{tabular}

\section{Kadar Air}

Kadar air dari bahan baku teh daun pegagan yaitu $4,05 \%$. Kadar air bahan baku teh daun pegagan memenuhi persyaratan SNI teh hijau 01-4453-1998 yaitu maksimal $8 \%$. Air merupakan komponen utama yang sangat penting dalam bahan pangan karena kandungan air pada bahan akan mempengaruhi terhadap umur simpannya. Teh merupakan bahan yang mempunyai sifat higroskopis, sehingga pengemasan merupakan faktor penting untuk penyimpanan teh kering. 


\section{Kadar Abu}

Kadar abu dari bahan baku teh daun pegagan yaitu $13,22 \%$. Kadar abu pada teh daun pegagan lebih tinggi dibandingkan dengan kadar abu pada teh hijau dari tanaman teh. Hal ini terlihat dari SNI teh hijau 01-4453-1998 yaitu maksimal 8\%. Hasil ini diperoleh karena sampel yang digunakan dalam penelitian berbeda dari sifat fisik dan kandungan senyawa tanaman teh (Camellia sinensis). Penelitian Marliani et al., (2011) mendapatkan kadar abu dari simplisia herba pegagan yaitu $18,66 \%$ lebih tinggi dari hasil penelitian yang didapat. Faktor ini dikarenakan tingginya kandungan garam mineral yang terdapat pada daun pegagan seperti kalium, natrium, magnesium, kalsium dan zat besi (Dalimartha, 2005).

\section{Analisis teh daun pegagan dengan penambahan ekstrak peppermint}

\section{Kadar Air}

Hasil sidik ragam kadar air teh daun pegagan menunjukkan bahwa penambahan ekstrak peppermint berpengaruh nyata terhadap teh daun pegagan yang dihasilkan. Nilai rata-rata kadar air pada teh daun pegagan dapat dilihat pada Tabel 2 .

Tabel2. Rata-rata kadar air teh daun pegagan

\begin{tabular}{cc}
\hline $\begin{array}{c}\text { Perlakuan } \\
\text { Penambahan ekstrak } \\
\text { peppermint }\end{array}$ & Kadar Air (\%) \\
\hline $4 \%$ & $4,10 \pm 0,06^{\mathrm{a}}$ \\
$3 \%$ & $4,16 \pm 0,01^{\mathrm{b}}$ \\
$2 \%$ & $4,17 \pm 0,05^{\mathrm{b}}$ \\
$1 \%$ & $4,20 \pm 0,04^{\mathrm{b}}$ \\
$0 \%$ & $4,25 \pm 0,10^{\mathrm{b}}$ \\
\hline
\end{tabular}

$\mathrm{KK}=1,38 \%$

Keterangan: angka-angka pada lajur yang sama diikuti oleh superscript yang tidak sama berbeda nyata pada taraf $5 \%$ menurut DNMRT.

Kadar air yang didapat pada penelitian teh daun pegagan dengan penambahan peppermint berkisar antara 4,10\%-4,25\%. Kadar air tertinggi dihasilkan pada perlakuan
A yaitu $4,25 \%$, sedangkan kadar air terendah dihasilkan oleh perlakuan $\mathrm{E}$ yaitu $4,10 \%$. Hasil di atas menunjukkan semakin banyak penambahan ekstrak peppermint terhadap teh daun pegagan maka kadar air yang dihasilkan semakin menurun. Hal ini terjadi karena adanya penguapan ekstrak peppermint selama proses kadar air berlangsung. Menurut Primadiati (2002) ekstrak peppermint tergolong kedalam minyak atsiri yang bersifat volatile dan mudah menguap.

Berdasarkan SNI Teh Hijau 01-44531998 nilai kadar air untuk produk teh hijau maksimal $8 \%$. Ini menandakan bahwa produk teh daun pegagan dengan penambahan ekstrak peppermint tidak melampaui batas maksimal kadar air SNI Teh Hijau 01-4453-1998.

\section{Kadar Abu}

Hasil sidik ragam kadar abu teh daun pegagan menunjukkan bahwa penambahan ekstrak peppermint berpengaruh nyata terhadap teh daun pegagan yang dihasilkan. Nilai rata-rata kadar abu pada teh daun pegagan dapat dilihat pada Tabel 3 .

Tabel3. Rata-rata kadar abu teh daun pegagan

\begin{tabular}{cc}
\hline $\begin{array}{c}\text { Perlakuan } \\
\begin{array}{c}\text { Penambahan ekstrak } \\
\text { peppermint }\end{array}\end{array}$ & Kadar Abu (\%) \\
\hline $0 \%$ & $4,10 \pm 0,06^{\mathrm{a}}$ \\
$1 \%$ & $13,88 \pm 0,08^{\mathrm{ab}}$ \\
$2 \%$ & $14,01 \pm 0,07^{\mathrm{bc}}$ \\
$3 \%$ & $14,14 \pm 0,11^{\text {cd }}$ \\
$4 \%$ & $14,23 \pm 0,15^{\mathrm{d}}$ \\
\hline $\mathrm{KK}=0,72 \%$ & \\
\hline
\end{tabular}

Keterangan: Angka-angka pada lajur yang sama diikuti oleh superscript yang tidak sama berbeda nyata pada taraf $5 \%$ menurut DNMRT.

Kadar abu teh daun pegagan dengan penambahan ekstrak peppermint dihasilkan antara $13,74 \%$ sampai $14,23 \%$. Nilai terendah terdapat pada perlakuan $0 \%$ dan nilai tertinggi terdapat pada perlakuan $4 \%$. Hasil ini berbeda dengan standar SNI teh hijau 01-4453-1998 yang menyebutkan 
bahwa kadar abu maksimal yaitu $8 \%$. Perbedaan ini terjadi karena jenis bahan baku yang digunakan serta kandungan kimia yang berbeda dimana penelitian ini menggunakan daun pegagan dan ekstrak peppermint sedangkan didalam SNI teh hijau 01-4453-1998 tanaman yang digunakan yaitu teh (Camellia sinensis). Total abu yang terdapat pada daun pegagan seperti kalium, natrium, magnesium, kalsium dan zat besi, klorida, sulphat, phospat (Dalimartha, 2005 ; Singh, Gautam, Sharma dan Batra, 2010).

\section{Aktivitas Antioksidan Metode DPPH}

Hasil sidik ragam terhadap uji antioksidan dengan DPPH teh daun pegagan menunjukkan bahwa penambahan ekstrak peppermint berpengaruh nyata terhadap teh daun pegagan yang dihasilkan. Nilai rata-rata aktivitas antioksidan dengan DPPH pada teh daun pegagan dapat dilihat pada Tabel 4.

Tabel4. Rata-rata aktivitas antioksidan metode DPPH teh daun pegagan pada konsentrasi $100 \mathrm{ppm}$

\begin{tabular}{cc}
\hline $\begin{array}{c}\text { Perlakuan } \\
\text { Penambahan ekstrak } \\
\text { peppermint }\end{array}$ & $\begin{array}{c}\text { Kadar Oksigen } \\
(\%)\end{array}$ \\
\hline $0 \%$ & $12,77 \pm 1,50^{\mathrm{a}}$ \\
$1 \%$ & $15,97 \pm 1,30^{\mathrm{a}}$ \\
$2 \%$ & $23,75 \pm 1,90^{\mathrm{b}}$ \\
$3 \%$ & $34,60 \pm 3,11^{\mathrm{c}}$ \\
$4 \%$ & $55,22 \pm 2,00^{\mathrm{d}}$ \\
\hline
\end{tabular}

$\mathrm{KK}=7,26 \%$

Keterangan: Angka-angka pada lajur yang sama diikuti oleh superscript yang tidak sama berbeda nyata pada taraf $5 \%$ menurut DNMRT.

Aktivitas antioksidan dengan DPPH pada teh daun pegagan dengan penambahan peppermint berkisar antara $12,77 \%-55,22 \%$ pada konsentrasi $100 \mathrm{ppm}$. Nilai tertinggi terdapat pada perlakuan $4 \%$ yaitu $55,22 \%$. Hasil uji antioksidan dengan DPPH yang terendah terdapat pada perlakuan $0 \%$ yaitu $12,77 \%$.

Hasil sidik ragam di atas terlihat bahwa semakin banyak penambahan ekstrak peppermint maka aktifitas antioksidannya semakin meningkat. Hal ini disebabkan kandungan dari ekstrak peppermint memiliki senyawa limonene, cineole, menthone, menthol serta pulegone (Alankar, 2009), polifenol (19\%), karoten, dan tokoferol yang bertindak sebagai antioksidan (Gardiner, 2000). Selain itu pada tanaman pegagan sendiri juga memiliki kandungan antioksidan seperti flavonoid yang memiliki turunan flavonol (kuersetin dan kaemferol), karotenoid (Lasmadiwati et al., 2004). Rahman et al (2013) komponen kimia yang berfungsi sebagai antioksidan pada daun pegagan adalah polifenol, flavonoid, $\beta$ karoten, tannin dan vitamin $C$. Penelitian Subban et al., (2008) menemukan dua senyawa baru flovonoid yang berasal dari pegagan yaitu castilliferol dan castillicetin dan kedua senyawa ini memiliki aktivitas antioksidan.

Kandungan glikosida triterpenoid yaitu asiaticosida juga merupakan salah satu antioksidan pada pegagan yang berperan dalam merevitalisasi peredaran darah ke otak menjadi lancar, meningkatkan daya ingat dan melindungi sel sel otak dari kerusakan oksidatif akibat radikal bebas (Prabowo, 2002). Daun peppermint memiliki kekuatan yang sangat tinggi sebagai antioksidan primer yang bereaksi dengan senyawa radikal bebas. Polifenol merukanan komponen yang bertanggung jawab sebagai antioksidan (Nickavar, Alinaghi dan Kamalinejad, 2008)

\section{Kandungan Senyawa Triterpenoid dan Steroid Kualitatif}

Hasil uji kualitatif senyawa golongan triterpenoid pada teh daun pegagan dapat dilihat pada Tabel 5. Analisis uji kualitatif triterpenoid dilakukan dengan menggunakan metode Liebermen Burchard dimana sampel dilihat secara kasat mata untuk melihat ada atau tidaknya mengandung triterpenoid. Berdasarkan hasil didapat bahwa pada teh daun pegagan dengan penambahan peppermint positif (+) mengandung triterpenoid.

Januwati dan Yusron (2004) menyebutkan dalam penelitiannya mengenai uji fitokimia daun pegagan terdapat kandungan triterpenoid. Berdasarkan Verma et al., 
(2010) daun peppermint mengandung terpenoid berkisar antara $0.35 \%$ sampai $1,2 \%$ tergantung pada varietasnya. Menurut Fahmi (2002), terpenoid khususnya triterpenoid merupakan kandungan utama pegagan, terdiri atas asiaticosida, sentelosida, madekasosida, brahmosida dan brahminosida (glikosida saponin), asam asiaticentoic, asam centellic, asam centoic dan asam madekasat. Lucida and Wallace (1998) melaporkan bahwa ekstrak peppermint juga memiliki kandungan triterpenoid dalam jumlah yang kecil seperti: squalene, asam urosolic, a-amyrin dan sitosterol. Uji steroid pada teh daun pegagan dapat dilihat pada Tabel 6 .

Tabel5. Hasil analisis uji senyawa Triterpenoid teh daun pegagan

\begin{tabular}{cc}
\hline $\begin{array}{c}\text { Perlakuan } \\
\text { Penambahan ekstrak } \\
\text { peppermint }\end{array}$ & $\begin{array}{c}\text { Hasil Uji } \\
\text { Triterpenoid }\end{array}$ \\
\hline $0 \%$ & + \\
$1 \%$ & + \\
$2 \%$ & + \\
$3 \%$ & + \\
$4 \%$ & + \\
\hline
\end{tabular}

Keterangan: (+) mengandung senyawa uji triterpenoid

Tabel6. Hasil analisis uji senyawa Steroid teh daun pegagan

\begin{tabular}{cc}
\hline $\begin{array}{c}\text { Perlakuan } \\
\text { Penambahan ekstrak } \\
\text { peppermint }\end{array}$ & $\begin{array}{c}\text { Hasil Uji } \\
\text { Steroid }\end{array}$ \\
\hline $0 \%$ & + \\
$1 \%$ & + \\
$2 \%$ & + \\
$3 \%$ & + \\
$4 \%$ & + \\
\hline
\end{tabular}

Keterangan: $(+)$ mengandung senyawa uji steroid

Berdasarkan Tabel 6 didapat bahwa teh daun pegagan dengan penambahan ekstrak peppermint memiliki kandungan steroid hal ini ditandai dengan terbentuknya warna hijau (+) yang diuji menggunakan metode Liebermen Burchard.
Steroid dapat dikelompokkan menjadi sterol, sterolin, saponin (sapogenin), glikosida jantung, dan asam empedu. Sterol alam selalu mempunyai gugus hidroksi pada posisi $\mathrm{C}_{3}$ dan rantai samping $\mathrm{C}_{17}$ serta kadang-kadang berikatan rangkap pada posisi ikatan 5 - 6, contoh: stigmasterol, $\beta$ sitosterol, dan lain-lain (Robinson, 1995).

\section{Alkaloid Kualitatif}

Hasil uji kualitatif alkaloid pada teh daun pegagan dapat dilihat pada Tabel 7 .

Tabel 7. Hasil analisis uji alkaloid teh daun pegagan

\begin{tabular}{cc}
\hline $\begin{array}{c}\text { Perlakuan } \\
\begin{array}{c}\text { Penambahan ekstrak } \\
\text { peppermint }\end{array}\end{array}$ & $\begin{array}{c}\text { Hasil Uji } \\
\text { Alkaloid }\end{array}$ \\
\hline $0 \%$ & + \\
$1 \%$ & + \\
$2 \%$ & + \\
$3 \%$ & + \\
$4 \%$ & + \\
\hline
\end{tabular}

Keterangan: $(+)$ mengandung alkaloid

Hasil positif alkaloid pada uji Dragendorff ditandai dengan terbentuknya endapan kecoklatan pada teh daun pegagan dengan penambahan ekstrak peppermint. Singh et al, 2010 menyebutkan bahwa kandungan alkaloid yang terdapat pada pegagan yaitu alkaloid hidrokotilina. Pada ekstrak peppermint juga mengandung senyawa alkaloid sebagaimana yang dilaporkan oleh Sujana et al., (2013) didalam penelitiannya tentang uji antibakteri dan analisis fitokimia pada peppermint (Mentha piperita, L.). Alkaloid didefinisikan sebagai senyawa bersifat basa, mengandung atom nitrogen yang berasal dari tumbuhan dan hewan, berbentuk cincin heterosiklik, dan bersifat aktif biologis.

\section{Kandungan Total Polifenol}

Hasil sidik ragam terhadap uji kandungan total polifenol teh daun pegagan menunjukkan bahwa penambahan ekstrak peppermint berpengaruh nyata terhadap teh daun pegagan yang dihasilkan. Nilai rata- 
rata total polifenol pada teh daun pegagan dapat dilihat pada Tabel 8 .

Tabel 8. Rata-rata total polifenol teh daun pegagan pada konsentrasi $100 \mathrm{ppm}$

\begin{tabular}{cc}
\hline $\begin{array}{c}\text { Perlakuan } \\
\text { Penambahan ekstrak } \\
\text { peppermint }\end{array}$ & $\begin{array}{c}\text { Total Polifenol } \\
(\%)\end{array}$ \\
\hline $0 \%$ & $6,43 \pm 0,20^{\mathrm{a}}$ \\
$1 \%$ & $7,44 \pm 0,24^{\mathrm{ab}}$ \\
$2 \%$ & $8,31 \pm 0,53^{\mathrm{b}}$ \\
$3 \%$ & $10,66 \pm 0,96^{\mathrm{c}}$ \\
$4 \%$ & $11,88 \pm 0,90^{\mathrm{d}}$ \\
\hline
\end{tabular}

$\mathrm{KK}=1,44 \%$

Keterangan: Angka-angka pada lajur yang sama diikuti oleh superscript yang tidak sama berbeda nyata pada taraf $5 \%$ menurut DNMRT.

Total polifenol pada teh daun pegagan dengan penambahan ekstrak peppermint berkisar antara $6,43 \%-11,88 \%$ pada konsentrasi $100 \mathrm{ppm}$ asam galat. Nilai tertinggi terdapat pada perlakuan $4 \%$ yaitu $11,88 \%$. Total polifenol yang terendah terdapat pada perlakuan $0 \%$ yaitu $6,43 \%$. Dari hasil terlihat bahwa semakin banyak penambahan ekstrak peppermint maka total polifenol pada teh daun pegagan semakin meningkat. Total polifenol yang terdapat pada daun peppermint berkisar antara $150 \mu \mathrm{g} / \mathrm{mg}-450 \mu \mathrm{g} / \mathrm{mg}$ tergantung pada varietasnya (Nickavar et al, 2008). Pegagan juga banyak memiliki kandungan fenol (flavonoid) yaitu flavonol terdiri dari kuersetin dan kaemferol. Menurut Robinson (1995), flavonol paling sering terdapat sebagai glikosida, biasanya 3-glikosida, dan aglikon flavonol yang umum yaitu kamferol, kuersetin, dan mirisetin yang berkhasiat sebagai antioksidan.

\section{Organoleptik Warna}

Hasil pengujian warna teh daun pegagan terhadap 20 orang panelis dapat dilihat pada Tabel 9. Berdasarkan Tabel 9, warna pada teh daun pegagan dengan penambahan ekstrak peppermint dari lima perlakuan yang disukai oleh panelis adalah perlakuan penambahan ekstrak peppermint $1 \%$ dengan tingkat persentase suka dan sangat suka yaitu $100 \%$. Untuk tingkat penerimaan penelis terendah terdapat pada perlakuan $0 \%$ yaitu $45 \%$.

Warna teh daun pegagan dengan penambahan ekstrak peppermint yaitu hijau kekuningan mirip dengan warna seduhan teh hijau yang ada di pasaran. Komponen pemberi warna pada teh daun pegagan dengan penambahan ekstrak peppermint diduga kandungan flavonoid (flavonol) yang memiliki turunan kuersetin yang berperan dalam pembentukan warna kuning pada daun pegagan. Pada peppermint terkandung senyawa klorofil yang berfungsi sebagai pembentukan warna hijau pada tanaman mint seperti yang dilaporkan oleh Dambrauskiene et al., (2008) dalam penelitiannya mengenai produktivitas dan kandungan kimia pada Menthapiperita, L. dari sumber yang berbeda.

Tabel9. Hasil pengujian warna terhadap teh daun pegagan

\begin{tabular}{|c|c|c|c|c|c|c|}
\hline \multirow{2}{*}{$\begin{array}{l}\text { Perla- } \\
\text { kuan }\end{array}$} & & \multicolumn{4}{|c|}{ Tingkat Kesukaan Panelis (\%) } & \multirow{2}{*}{$\begin{array}{c}\text { SS+ } \\
\text { S }\end{array}$} \\
\hline & STS & TS & $B$ & S & SS & \\
\hline $0 \%$ & 0 & 0 & 55 & 45 & 0 & 45 \\
\hline $1 \%$ & 0 & 0 & 0 & 45 & 55 & 100 \\
\hline $2 \%$ & 0 & 0 & 25 & 70 & 5 & 75 \\
\hline $3 \%$ & 0 & 0 & 30 & 65 & 5 & 70 \\
\hline
\end{tabular}

Tidak Suka, dan STS = Sangat Tidak Suka

\section{Rasa}

Hasil pengujian rasa teh daun pegagan terhadap 20 orang panelis dapat dilihat pada Tabel 10. Berdasarkan Tabel 10, rasa pada teh daun pegagan dengan penambahan ekstrak peppermint dari lima perlakuan yang disukai oleh panelis adalah perlakuan penambahan ekstrak peppermint 3\% dengan tingkat persentase suka dan sangat suka yaitu $100 \%$. Untuk tingkat penerimaan penelis terendah terdapat pada perlakuan tanpa penambahan ekstrak peppermint yaitu $35 \%$. Ini mengindikasikan bahwa semakin banyak penambahan ekstrak peppermint sampai rentang $3 \%$ maka tingkat kesukaan panelis terhadap rasa juga semakin tinggi.

Pada penambahan ekstrak peppermint $4 \%$ panelis masih menyukainya dengan nilai 95\%. Ekstrak peppermint jika ditambahkan dalam konsentrasi yang lebih tinggi di atas 
$4 \%$ maka rasanya akan pahit serta menimbulkan rasa pedas ketika diseduh. Pada daun pegagan memiliki rasa pahit dan sepat yang dikarenakan pegagan memiliki kandungan alkaloid yaitu alkaloid hidrokotilina (Sing et al, 2010). Tujuan dari penambahan ekstrak peppermint untuk mengurangi rasa sepat dan pahit yang terkandung pada pegagan serta menimbulkan unsur kesegaran serta memiliki citarasa (flavour) minty yang khas ketika diseduh karena mengandung mentol pada peppermint.

Tabel 10. Hasil pengujian rasa terhadap teh daun pegagan

\begin{tabular}{ccccccc}
\hline \multirow{2}{*}{$\begin{array}{c}\text { Perla- } \\
\text { kuan }\end{array}$} & \multicolumn{5}{c}{ Tingkat Kesukaan Panelis (\%) } & SS+S \\
\cline { 2 - 5 } & ST & TS & B & SS & \\
\hline$\%$ & 0 & 5 & 65 & 30 & 0 & 30 \\
$1 \%$ & 0 & 10 & 45 & 45 & 0 & 145 \\
$2 \%$ & 0 & 0 & 35 & 60 & 5 & 65 \\
$3 \%$ & 0 & 0 & 0 & 15 & 85 & 100 \\
$4 \%$ & 0 & 0 & 0 & 65 & 30 & 95 \\
\hline
\end{tabular}

Ket: $\mathrm{SS}=$ Sangat Suka, $\mathrm{S}=$ Suka, $\mathrm{B}=$ Biasa, $\mathrm{TS}=$ Tidak Suka, dan STS = Sangat Tidak Suka

\section{Aroma}

Hasil pengujian aroma teh daun pegagan terhadap 20 orang panelis dapat dilihat pada Tabel 11.

Tabel 11. Hasil pengujian aroma terhadap teh daun pegagan

\begin{tabular}{ccccccc}
\hline \multirow{2}{*}{$\begin{array}{c}\text { Perla- } \\
\text { kuan }\end{array}$} & \multicolumn{5}{c}{ Tingkat Kesukaan Panelis (\%) } & SS+S \\
\cline { 2 - 5 } & STS & TS & B & S & SS & \\
\hline $0 \%$ & 0 & 0 & 75 & 25 & 0 & 25 \\
$1 \%$ & 0 & 0 & 35 & 55 & 10 & 65 \\
$2 \%$ & 0 & 0 & 10 & 85 & 5 & 90 \\
$3 \%$ & 0 & 0 & 15 & 70 & 15 & 85 \\
$4 \%$ & 0 & 0 & 5 & 40 & 55 & 95 \\
\hline
\end{tabular}

Ket: SS = Sangat Suka, $S=$ Suka, $B=$ Biasa, TS = Tidak Suka, dan STS $=$ Sangat Tidak Suka

Berdasarkan Tabel 11, aroma pada teh daun pegagan dengan penambahan ekstrak peppermint dari lima perlakuan yang disukai oleh panelis adalah perlakuan $4 \%$ dengan tingkat persentase suka dan sangat suka yaitu $95 \%$. Untuk tingkat penerimaan penelis terendah terdapat pada perlakuan $0 \%$ yaitu $25 \%$. Aroma yang dihasilkan pada teh daun pegagan dengan penambahan peppermint yaitu aroma yang khas serta segar dikarenakan peppermint memiliki komponen aroma seperti menthone, isomenthone, menthofuran, carvone, linalool and piperitone oxide (Verma et al., 2010).

Peranan aroma suatu produk sangat penting karena akan menentukan daya terima konsumen terhadap produk tersebut. Aroma juga menentukan kelezatan suatu produk pangan, serta cita rasa yang terdiri dari tiga komponen, yaitu bau, rasa dan rangsangan mulut. Kandungan peppermint juga mengandung menthol dimana menthol merupakan senyawa aromatis yang berbau tajam dan bersifat volatile atau mudah menguap (Abbas, 2005). Disamping itu, penelitian Ghassani (2009) menyatakan bahwa aroma dari peppermint efektif dapat meningkatkan performansi memori jangka pendek pada mahasiswa.

Berdasarkan hasil uji organoleptik dengan lima parameter penilaian yang digunakan yaitu 1 = Sangat Tidak Suka (STS), 2 = Tidak Suka (TS), 3 = Biasa (B), 4 = Suka (S), dan 5 = Sangat Suka (SS) terhadap warna, aroma, dan aroma yang dihasilkan dapat diambil satu perlakuan yang paling disukai oleh panelis. Dimana dalam menentukan satu perlakuan yang paling disukai panelis dapat dilihat pada Tabel 12.

Tabel 12. Resume hasil uji organoleptik teh daun pegagan

\begin{tabular}{ccccc}
\hline \multirow{2}{*}{ Perlakuan } & \multicolumn{4}{c}{ Parameter Suka + Sangat Suka } \\
\cline { 2 - 5 } & Warna & Rasa & Aroma & Jumlah \\
\hline $0 \%$ & $45 \%$ & $30 \%$ & $25 \%$ & $100 \%$ \\
$1 \%$ & $100 \%$ & $45 \%$ & $65 \%$ & $210 \%$ \\
$2 \%$ & $75 \%$ & $65 \%$ & $90 \%$ & $230 \%$ \\
$3 \%$ & $70 \%$ & $100 \%$ & $85 \%$ & $255 \%$ \\
$4 \%$ & $70 \%$ & $95 \%$ & $95 \%$ & $260 \%$ \\
\hline
\end{tabular}

Berdasarkan Tabel 12 disimpulkan bahwa perlakuan yang disukai oleh panelis secara keseluruhan yang meliputi warna, rasa, dan aroma teh daun pegagan dengan penambahan ekstrak peppermint yaitu perlakuan $4 \%$ dengan total nilai persentase keseluruhan $260 \%$. 


\section{KESIMPULAN}

Berdasarkan penelitian yang telah dilakukan dapat diambil kesimpulan bahwa penambahan ekstrak peppermint berpengaruh nyata terhadap kadar air, kadar abu, total polifenol, dan aktivitas antioksidan teh daun pegagan yang dihasilkan. Perlakuan yang disukai oleh panelis berdasarkan uji organoleptik yaitu penambahan ekstrak peppermint $4 \%$ dengan hasil analisis kadar air 4,10\%, kadar abu $14,23 \%$, total polifenol $11,88 \%$, dan aktivitas antioksidan $55,22 \%$.

\section{DAFTAR PUSTAKA}

Abbas, A. 2005. The yield and essential oil content of mint (Mentha ssp.) in Northern Ostrobothnia, Faculty of Science, Department of Biology, University of Oulu, Oulu university Press, Oulu, Finland, p. 16-41.

Alankar, S. 2009. A review on peppermint oil. Asian Journal of Pharmaceutical And Clinical Research.

Anggia, M. 2011. Pengaruh penambahan Cassiavera terhadap penerimaan dan daya antioksidan minuman celup (teh hitam, teh hijau, dan daun kahwa). Universitas Andalas. Padang.

AOAC. 1995. Officials methods of analysis of the asociation of official analitycal chemistry. Washington DC.

Dalimartha,S. 2005. Atlas tumbuhan obat Indonesia Jilid I. Trubus Agriwidya, Jakarta.

Dambrouskiene, E., P. Viskelis, and R. Karkleliene, 2008. Productivity and biochemical composition of Mentha piperita L. of Different Origin. Biological. Vol. 54. No.2. P. 105-107.

Fahmi, R. 2002. Uji kandungan metabolit sekunder. Makalah dalam Workshop Peningkatan Sumber Daya Manusia, Kajian Kimia Organik Bahan Alam Hayati dan Pelestarian Hutan, 21-27 Juli 2002 di Padang.
Gardiner, P. 2000. Peppermint (Mentha piperita). The Center for Holistic Education and Research. Revised May 2,1-22.

Ghasani, A., dan M.E. Bhinnety. 2009. Efektivitas aroma peppermint untuk meningkatkan performansi memori jangka pendek pada mahasiswa. Fakultas Psikologi : Universitas Gajah Mada.

Irwanto, S. 2012. Studi pembuatan teh pucuk gambir bercita rasa Cassiavera. Universitas Andalas. Padang.

Januwati, M. dan M. Yusron. 2004. Standard operasional, budidaya pegagan, lidah buaya, sambiloto, dan kumis kucing. Circular No. 9. Balittro. hal. 1-6. Bogor.

Lasmadiwati, E., M. M. Herminati dan Y.H. Indriani. 2003. Pegagan. $69 \mathrm{hlm}$. Penebar Swadaya. Jakarta.

Lucida, G.M., and J.M. Wallace. 1998. In : Herbal Medicines, A Clinicians Guide. Pharmaceuticl Products Press, New York, London, 85-86.

Mahapatra, KD, Kumar B. 2012. Ancient and pharmacological review on cetella asiatica : A Potential Herbal Panacea. International Journal of Research and Reviews in Pharmacy and pplied Science. Dec 2 (6) 1062-1072.

Marliani, L., A. Nawawi, dan F. Faizal. 2011. Pemanfaatan ekstrak pegagan sebagai minuman kesehatan dalam bentuk jelly. Prosiding SNaPP2011 Sains, Teknologi, dan Kesehatan. Hal 201206.

Nickavar, B, Alinaghi A dan Kamalinejad, 2008. Evaluation on the antioxidant properties of five mentha species. Irranian Journal of Pharmaceutical Research 7(3): 203-209.

Prabowo, W. 2002. Centella anti radang. PT Intisari Mediatama. Jakarta. 
Primadiati, R. 2002. Aromaterapi. Jakarta : PT. Gramedia Pustaka Utama.

Putri, H. S. 2012. Pengaruh penambahan daun surian (Toona sureni, BI, Merr) dan lama perebusan daun papaya (Carica papaya, L.) terhadap kualitas mie basah daun papaya. Universitas Andalas. Padang.

Rahayu, W.P. 1994. Penilaian Organoleptik, Penuntun Praktikum. Fakultas Teknologi Pertanian. Institut Pertanian Bogor. Bogor.

Rahman M, Hossain S, Rahaman A, Fatima $\mathrm{N}$, Nahar T, Uddin B dan Basunia MA. 2013. Antioxidant activity of centella asiatica (Linn) Urban : Impact of Extraction Solvent Polarity. Journal of Pharmacognosy and Phytochemistry.

Robinson, T. 1995, Kandungan organik tumbuhan tinggi, ITB, Bandung.

Singh, S., Gautam, A., Sharma, A., dan Batra, A. 2010. Centella asiatica (L) : A plant with immerse medicinal potential but threatened. International Journal of Pharmaceutical Sciences Review and Research.

Subban, R., A. Veerakumar, and R. Manimaran. 2008. Two new flavonoids from centella asiatica (Linn.). Journal of Natural Medicine 62: 369-373.
Sudarmadji, S., B. Haryono, dan Suhardi. 1997. Prosedur analisa untuk bahan makanan dan pertanian (edisi keempat). Liberty. Yogyakarta.

Sujana, P., T.M. Sridhar, P. Josthna, and C.V. Naidu. 2013. Antibacterial activity and phytochemical analysis of mentha piperita L. (Peppermint)-An Important Multipurpose Medical Plant. American Journal of Plant Sciences, 4, 77-83.

Taga, M. S., Miller, E. E., and Pratt, D. E. (1984). Chia seeds as a source of natural lipid antioxidants. Journal of the American Oil Chemists' Society, 61, 928-931

Verma, RS, Rahman L, Verma RK, Chauhan A, Yadav AK dan Singh, 2010. Essential oil composition of menthol mint (mentha arvensis) and pepermint (mentha piperita) cultivars at different stages of plants growth from Kumaon Region of Western Himalaya. Open Access Journal of Medicinal and Aromatic Plants Vol 1(1): 13-18.

Wahyuningsih, M.S.H. 2011. Deskriptif penelitian dasar herbal medicine. Bagian Farmasi Kedokteran, Fakultas Kedokteran Universitas Gajah Mada. Yogyakarta.

Winarto, W.P. dan M. Surbakti. 2003. Khasiat dan manfaat pegagan. Agromedia Pustaka, Jakarta. 